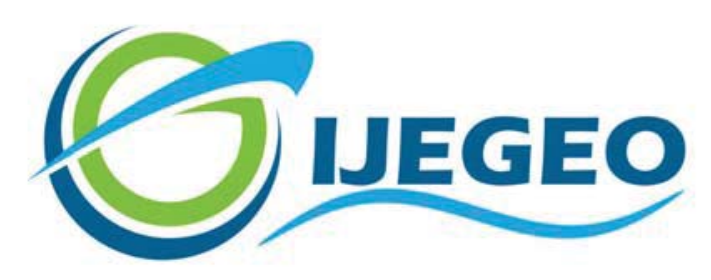

International Journal of Environment and Geoinformatics (IJEGEO) is an international, multidisciplinary, peer reviewed, open access journal.

\title{
Historical Perspectives of Land Use and Land Cover Change in the Sanga-Lake Mburo former Pastoral Rangeland Ecosystem, Uganda
}

\section{Shadrack Murithi NJAGI, Julius LEJJU, John Bosco NKURUNUNUGI}

\author{
Chief in Editor \\ Prof. Dr. Cem Gazioğlu \\ Co-Editors Prof. Dr. Dursun Zafer Şeker, Prof. Dr. Şinasi Kaya, \\ Prof. Dr. Ayşegül Tanık and Assist. Prof. Dr. Volkan Demir
}

Editorial Committee (June 2022)

Assoc. Prof. Dr. Abdullah Aksu (TR), Assoc. Prof. Dr. Uğur Algancı (TR), Assoc. Prof. Dr. Aslı Aslan (US), Prof. Dr. Levent Bat (TR), Prof. Dr. Paul Bates (UK), İrşad Bayırhan (TR), Prof. Dr. Bülent

Bayram (TR), Prof. Dr. Luis M. Botana (ES), Prof. Dr. Nuray Çağlar (TR), Prof. Dr. Sukanta Dash (IN), Dr. Soofia T. Elias (UK), Prof. Dr. A. Evren Erginal (TR), Assoc. Prof. Dr. Cüneyt Erenoğlu (TR), Dr. Dieter Fritsch (DE), Prof. Dr. Ç; Prof. Dr. Manik Kalubarme (IN), Dr. Hakan Kaya (TR), Assist. Prof. Dr. Serkan Kükrer (TR), Assoc. Prof. Dr. Maged Marghany (MY); Prof. Dr. Micheal Meadows (ZA), Prof. Dr. Nebiye Musaoğlu (TR), Prof. Dr. Masafumi Nakagawa (JP), Prof. Dr. Hasan Özdemir (TR), Prof. Dr. Chyssy Potsiou (GR), Prof. Dr. Erol Sarı (TR), Prof. Dr. Maria Paradiso (IT), Prof. Dr. Petros Patias (GR), Prof. Dr. Elif Sertel (TR), Prof. Dr. Nüket Sivri (TR), Prof. Dr. Füsun Balık Şanlı (TR), Dr. Duygu Ülker (TR), Prof. Dr. Seyfettin Tsaş (TR), Assoc. Prof. Dr. Ömer Suat Taşkın (TR), Assist. Prof. Dr. Tuba Ünsal (TR), Assist. Prof. Dr. Sibel Zeki (TR) 


\title{
Historical Perspectives of Land Use and Land Cover Change in the Sanga-Lake Mburo former Pastoral Rangeland Ecosystem, Uganda
}

\author{
Shadrack Murithi Njagi iD, Julius Lejju iD, John Bosco Nkurunungi iD * \\ Department of Biology, Faculty of Science, Mbarara University of Science and Technology, P.O. Box 1410, Mbarara, UGANDA \\ * Corresponding author: J. B. Nkurunungi \\ Received: 24.09.2021 \\ E-mail: jnkurunungi@must.ac.ug \\ Accepted : 01.12.2021 \\ How to cite:Njagi et al., (2022). Historical Perspectives of Land Use and Cover Change in the Sanga-Lake Mburo former Pastoral Rangeland \\ Ecosystem, Uganda. International Journal of Environment and Geoinformatics (IJEGEO), 9(2):094-107, doi. 10.30897/ijegeo. 998420
}

\begin{abstract}
Socioeconomic, political, and policy decisions by the government may influence the socioecological changes of the land use and land cover pattern for rangeland people over time. This paper examines the historical political, policy, and socioeconomic decisions that influenced land use and land cover changes in the former pastoral community in Sanga-Lake Mburo Rangeland Ecosystem in South Western Uganda. Data on historical events were documented from literature and supplemented by an opportunistic discussion with Sanga residents. Data on land use and cover change detection between 1987 and 2020 were provided by Landsat 5 TM and Landsat 8 OLI/TIRS images and from field observations. Images were processed using QGIS version 3.20.1 employing a semi-automatic classification plugin. Political decisions and government policies related to land tenure and reforms, socioeconomics, and demographic changes were noted as underlying drivers of land use and cover changes. The overall accuracies for classified maps of 1987 and 2020 were $80.36 \%$ and $89.81 \%$, respectively. Notably, woodland cover in the protected area increased by $170.53 \%$ between 1987 and 2020, while built-up areas and farmland increased $1348.15 \%$ and $405.03 \%$, respectively. In the same period, wetland cover in protected and unprotected decreased immensely by $46.06 \%$. Bareland in the park decreased by $23 \%$, while outside the park, it increased by $25.07 \%$. This study concludes that land use and land cover change resulted from sociocultural changes, political and policy decisions on ranches, park management, and land tenure restructuring.
\end{abstract}

Keywords: Park, Political, Policy, Pastoralists, Vegetation, Sedentarization

\section{Introduction}

Globally, anthropogenic and natural factors are threatening rangeland ecosystems (Mugisha, 2002). Kimiti et al. (2016) report that since the 1950s, close to 10.7 million $\mathrm{km}^{2}$ of the global land occupied by woodland and grassland has been converted to farmlands. The decline in the rangeland ecosystem in Uganda is experienced more in the cattle corridor, which stretches from the southwestern part of Uganda to the northeastern part of the country (NEMA, 2007). According to Olson and Berry (2003), the primary land use and land cover (LULC) issues in rangeland ecosystems are bush burning, deforestation, overgrazing, and inappropriate farming practices. The rapid vegetation conversion to farmlands could be attributed to intensifying and modernizing agriculture (Sambou et al., 2015). For example, shifting cultivation in agricultural expansion is the leading cause of deforestation in the Equater region in the Democratic Republic of Congo (Samndong et al., 2018). In the northern Atlantic forest in Brazil, $76 \%$ of the households rely on fuelwood (Godar et al., 2014).

LULC changes such as the conversion of grassland or woodland to farmland can increase the changes associated with natural forces (Smith et al., 2014). Satellite, ground-based, and tower observations indicate deforestation occurs during drier and warm conditions at local scales (Lawrence and Vandecar, 2015). Agricultural productivity is lowered by these conditions, as pasture and soil moisture contents are reduced, leading to conflicts for resources, migration, biodiversity loss, and among others (Alkama and Cescatti, 2016; Barni et al., 2015; Kweka et al., 2016; Lapola et al., 2014; İşcan and Yağc1, 2017). Land use influences the nutrient distribution and their supply by causing the alteration of the soil property and controlling the activity of microbes near the root zones. Cultivation causes the soil carbon to diminish within a few years of the conversion (Murty et al., 2002), reducing carbon sequestration (Robert et al., 2020) and can substantially lower the mineralizable soil nitrogen (Richter et al., 2000). The topsoil organic diminishes, thus reducing the productivity (Majaliwa et al., 2010). Therefore, severe land degradation can result in a nutrient loss (Tukarhirwa, 2004).

The primary land use in Sanga was livestock grazing because most of the people in the region were pastoralists. However, with time, the pastoralists adopted a settled lifestyle and started crop farming alongside livestock keeping. Due to the population pressure and sedentarization (Greg et al., 2019), the pressure on land has increased due to the need for grazing land, cultivation, and settlement, thereby 
influencing the LULC changes (Mwanjolo et al., 2018). Furthermore, vegetation burning and livestock keeping in Sanga Subcounty cause the restructuring of landscapes and habitat modifications (Averbeck et al., 2012). The uncertain and erratic rainfall in rangelands can make rangeland ecosystems described as disequilibrium systems (Behnke and Scoones, 1992). The livestock production in such ecosystems is ideal when the livestock can be moved to locations with the best pasture at any time. However, sedentarization, land privatization, land subdivision, and population growth have made it hard for pastoralists to move their livestock from place to place (Mallarach, 2008). This problem is threatening their livelihood and affecting the land cover.

Currently, the conversion of natural ecosystems into other land use is a crucial challenge in Sanga. Since the park's creation in 1983 (Ayorekire et al., 2011; Hulme and Infield, 1998; Namara et al., 1994), there has been increased pressure on available natural resources such as woodland, soil, grassland, and wetlands. The creation of the national park in 1983 also reduced land for pastoralism (Ayorekire et al., 2011; Emerton, 1999b), causing more land crises due to reduced grazing land. Woody vegetations are highly exploited for shifting cultivation, wood, fuelwood, and charcoal (Basamba et al., 2016) as population increases and demand for construction and fuelwood increases (Elias et al., 2019). Within the cultivated land in Sanga, crop cultivation is intensifying, leading to land subdivisions. Furthermore, this rangeland experiences competition for forage and pasture by livestock and wildlife (Nyamasyo and Kihima, 2014) from the park. Moreover, the traditions and taboos that excluded farming communities from cultivating the landscape near Lake Mburo have changed, leading to the constant loss of the exclusive pastoralist landscapes (Mallarach, 2008). As a result of these changes, soil erosion is observed, wetlands and grazing lands are shrinking, and frequent droughts are experienced. We noted several studies in Uganda on LULC (Mbaziira, 2014, 2019; Mwanjolo et al., 2018; Nakalembe et al., 2017;
Solberg et al., 2018). However, none of the studies adequately addressed historical drivers of LULC change in ecosystems surrounding a park focusing on former pastoralists with a unique history.

Our study focused on assessing the historical drivers of LULC changes, mapping LULC, and quantifying LULC changes between 1987 and 2020. The purpose of our study was to highlight how political and policy decisions in the past, sociocultural and demographic changes affected the current LULC. The understanding of the causes of LULC changes and how LULC changed can be used for predicting future trends. This understanding is essential for sustainable land use by the people who depend on the fragile rangeland ecosystems, particularly in Sanga. We asked what the political and policy decisions, cultural and socioeconomic changes that influenced LULC changes are and how they influenced them. We also asked how LULC cover status was in 1987 and 2020, the cause of such status, the class of LULC that changed most, and the main drivers for the change.

\section{Materials and Methods \\ Area of study}

The study was conducted in Sanga rangeland located in Kiruhura District, South Western Uganda, located at $0^{\circ} 22^{\prime} 22.50^{\prime \prime S}$ to $0^{\circ} 42^{\prime} 39.59^{\prime \prime} \mathrm{S}$ and $30^{\circ} 47^{\prime} 06.04^{\prime \prime} \mathrm{E}$ to $31^{\circ} 0201.25^{\prime \prime E}$ (Fig 1) and with an elevation of about $1800 \mathrm{~m}$ above sea level. Temperature ranges from $17^{\circ} \mathrm{C}$ to $30^{\circ}$, and the region receives a double maximum rainfall pattern of $900 \mathrm{~mm}$ on average per year, which falls from March to May and August to October (Tibezinda et al., 2016). It is gently sloppy and with runoff during heavy rainfall. The area experiences unpredictable, scarce, and unreliable rainfall, which often leads to crop failure. The site has varying types of soils. In lowlands, the soil is black-grey, hard clay loams, reddish-brown with sandy structure. The vegetation comprises savannah (Basamba et al., 2016)). The main economic activity is pastoralism practiced by 70 percent of the population.

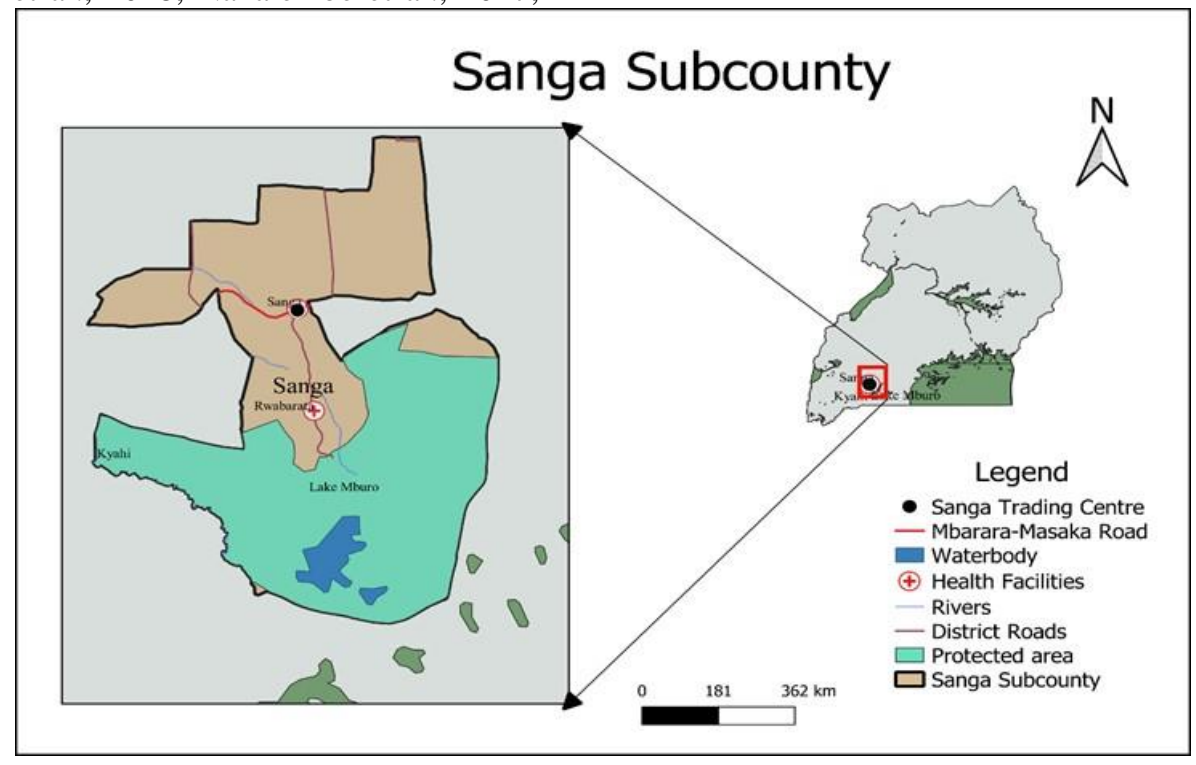

Fig. 1: Inset is a map of Uganda showing the location of the Sanga sub-county 


\section{Data collection}

Data on historical drivers of LULC change before and during the period under review -1987 to 2020 were obtained from published journals, working papers, thesis, government, and non-governmental reports on events. The literature materials were obtained from Google scholar and government and non-government websites by searching for land use in Sanga and Lake Mburo. We followed an approach called Preferred Reporting Items for Systematic Reviews and MetaAnalyses (PRISMA) (Luwa et al., 2020), which involved searching, screening, and considering the relevant materials. We searched 205 articles, discarded 100 articles for duplication, and screened the remaining 105. We considered thirty literature materials written in English. The literature materials included; three books, seven published journals, four research papers, seven working and discussion papers, three thesis, and six government and non-government reports. These data from literature were supplemented by opportunistic interactions with our field assistant, two local leaders, and seven other older people from Sanga. We preferred the PRISMA approach because it allows researchers to identify trends and common themes on quantitative and qualitative methods without the predefined bias of inclusion and exclusion (Luwa et al., 2020).

Table 1: The Landsat images used in the classification of LULC in the Sanga sub-county

\begin{tabular}{lcccl}
\hline Landsat & Year & Path/Row & $\begin{array}{l}\text { Band } \\
\text { combination }\end{array}$ \\
\hline $\begin{array}{l}\text { Landsat } \\
\text { TM }\end{array}$ & 5 & 1987 & $172 / 60$ & $7-5-4-3-2-1$ \\
$\begin{array}{l}\text { Landsat } \\
\text { OLI/TIRS }\end{array}$ & 8 & 2020 & $172 / 60$ & $7-6-5-4-3-2$ \\
Table 2 : & & &
\end{tabular}

Table 2: Sanga Subcounty LULC description as used in classification

\begin{tabular}{ll}
\hline $\begin{array}{l}\text { Land use and land cover } \\
\text { type }\end{array}$ & Description \\
\hline Eroded/Bare land & $\begin{array}{l}\text { The area with very little } \\
\text { or no vegetation cover } \\
\text { Natural grass or grass-like } \\
\text { vegetation } \\
\text { Opassland }\end{array}$ \\
Open water bodies, lakes, \\
and water dams \\
Permanently/seasonally \\
waterlogged areas with \\
vegetation cover \\
Area with woody \\
vegetation species both \\
natural and exotic \\
Artificial structures, \\
mainly the buildings \\
Cultivated areas with \\
perennial and annual \\
crops
\end{tabular}

Data on LULC changes were obtained from satellite images of Landsat from USGS Earth Explorer (https://earthexplorer.usgs.gov). Thematic Mapper (5 TM) images captured on February 1987 and Landsat 8 Operational Land Imager (OLI) and Thermal Infrared
Sensors (TIRS) images captured on January 2020 provided data on LULC changes between 1987 and 2020, as summarized in Table 1. LULC classes identified were farmland, grassland, woodland, bare land, wetlands, water body, and built-up areas. The description of these LULC is provided in Table 2 below. Ground truthing data through field observation were used to validate the 2020 map using 50 ground control points for each land cover class collected using a GPS. The interaction with our field assistant and nine other Sanga residents provided supplementary information about LULC change.

\section{Image processing and analysis}

1987 Landsat 5 TM and 2020 Landsat 8 OLI/TIRS images were imported into QGIS version 3.20.1 and bands loaded to semi-automatic classification plugin version 7.9.5(Congedo, 2021). Then the images were clipped to the area of interest, and then we enhanced the images by conducting DOS (Dark Object Subtraction) atmospheric correction. Supervised classification methods were used in the classification of the images and to produce maps for LULC by creating ROIs (Regions of Interest) after creating training inputs. The maximum likelihood function was used to generate land cover maps. Land cover classifiers most prefer this function because it produces precise results, and cluster statistics have a normal distribution (Sintayehu and Kassaw, 2019). LULC change detection was generated to show the conversions using the same tool and plugin. Accuracy assessments of maps were assessed using the Kappa statistic and error matrix (Mbaziira, 2019) to validate 1987 and 2020 classified maps. For 2020, ground truth data by field observations and from Google satellite images were used. Ground control points (GCP) were collected from the field using a GPS and others obtained from google satellite images, especially for land cover in the protected area. Besides field observation and the input of our assistants, Google satellites images provided further interpretations and accuracy assessment of the classified map for 2020. We collected 50 GCPs for each. 1987 mages interpretation was used in the accuracy assessment of the 1987 classified map, and GCPs were obtained through stratified sampling to determine the sample size using this formula (Olofsson et al., 2014);

$\mathrm{N}=\left(\sum i=1(\mathrm{~W} i * \mathrm{~S} i) / \mathrm{S} o\right)^{2} \ldots \ldots \ldots . .($ Eq. 1$)$

Where:

W $i=$ proportion of the mapped area of class $i$; $\mathrm{S} i=$ Stratum $i$ 's conjectured standard deviation; $\mathrm{S} o=$ the overall accuracy' expected standard deviation; $\mathrm{N}=$ total sample size.

A sample size of 882 of the total area of the Sanga subcounty was produced by conjecturing standard deviation of the strata and user's accuracy as recommended by Olofsson et al. (2014). A rough approximation for the sample size for each land 
use/cover class was determined by considering the mean value between weighted distribution $\left(\mathrm{N} i=\mathrm{N}^{*} \mathrm{~W} i\right)$ and equal distribution $(\mathrm{N} i=\mathrm{N} / \mathrm{c})$.

$$
(\mathrm{N} i=\mathrm{N} * \mathrm{~W} i+\mathrm{N} / \mathrm{c}) / 2 \ldots \ldots \ldots \text { (Eq. 2). }
$$

Where:

$\mathrm{C}=$ total number of classes (7);

$\mathrm{N} i=$ sample size of class $i$.

Thus, built-up had a sample size of 63 , farmland had 70 , bare land had 98, wetland had 126 , waterbody had 73 , grassland had 267, and woodland had 185 GCPs, respectively. The following equations were used in calculating land use/ cover change, percentage land use/cover change, and percentage rate of land/cover change;

LULC change $=$ CL-PL; percentage LULC change $=$ (CL-PL/PL)x 100 and percentage rate of LULC change $=$ percentage change/number of years.

Where; CL is the current LULC in 2020 and PL is the previous LULC in 1987.

\section{Results}

Historical drivers of LULC change before and between the years 1987 and 2020

Table 3 below lists the historical drivers of LULC change in Sanga, both in protected and unprotected areas, prior study, and during the study.

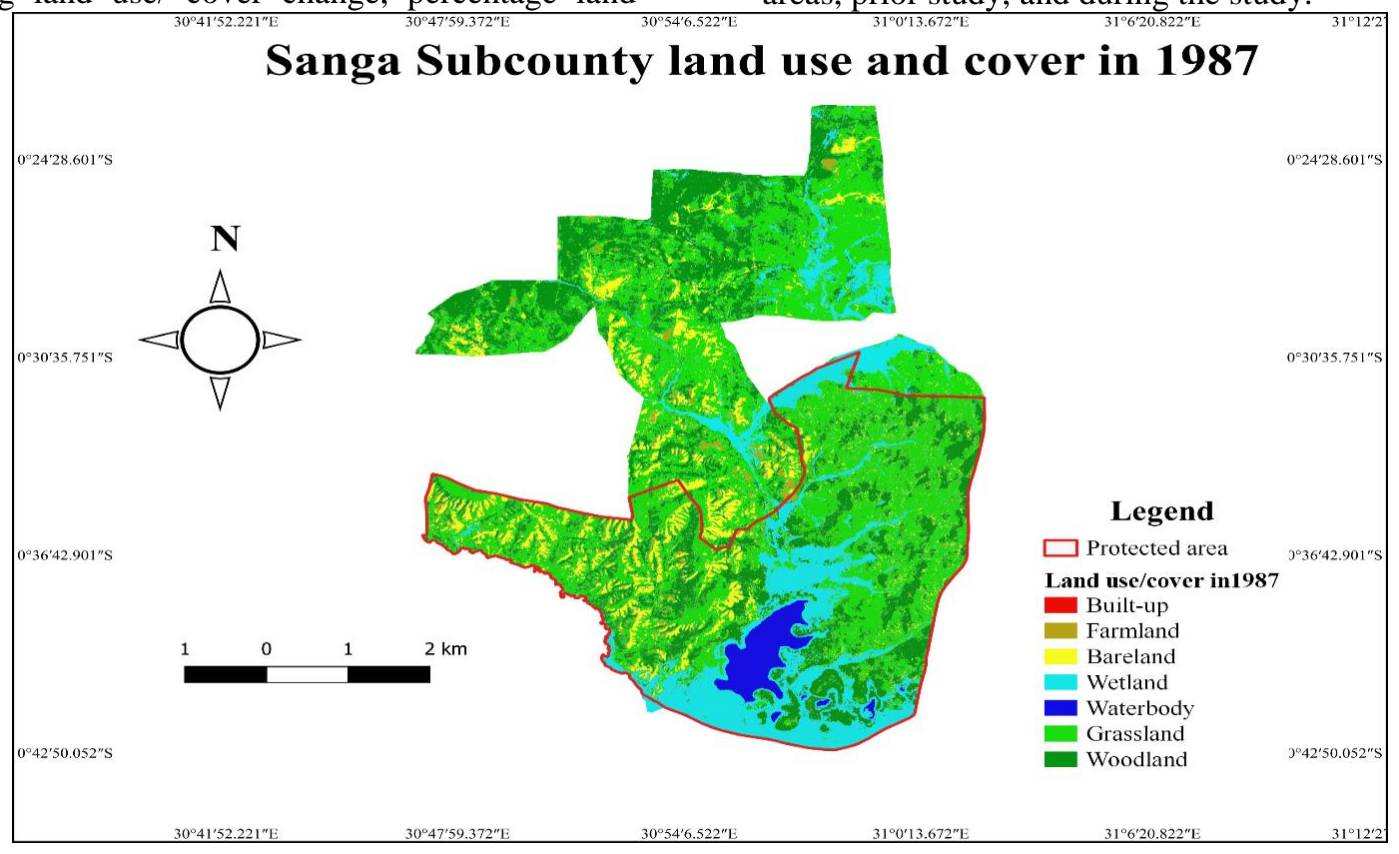

Fig. 2: LULC of Sanga Subcounty in 1987.

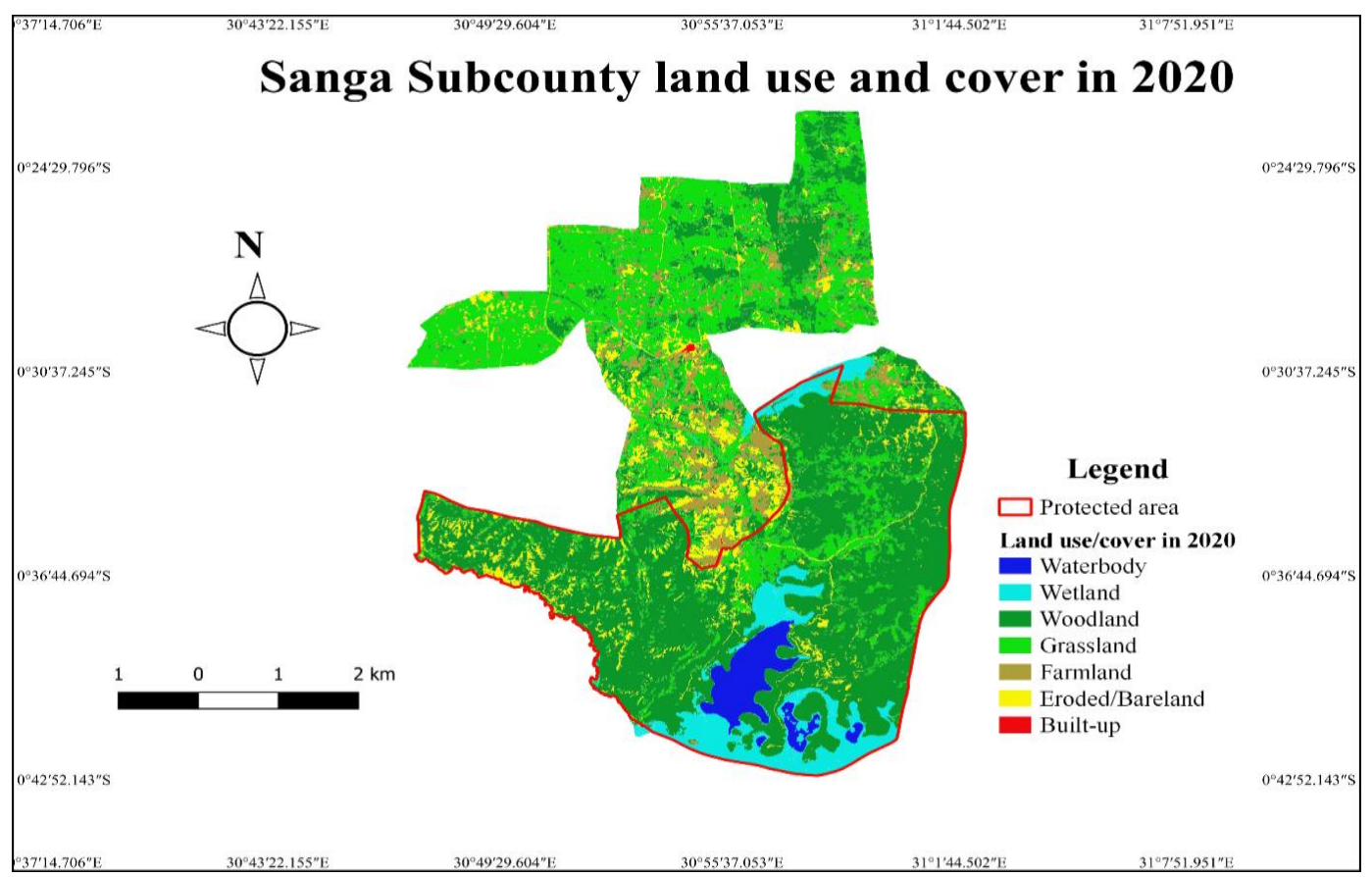

Fig. 3: LULC of Sanga Subcounty in 2020 
Table 3: Historical drivers of LULC before and during the study

\begin{tabular}{lcl}
\hline Date & Historical drivers of LULC change \\
\hline Pre-1970 & $\bullet$ & $\begin{array}{l}\text { Establishment of government-sponsored } \\
\text { ranches in the "cattle corridor" of Uganda }\end{array}$
\end{tabular}

- $\quad$ Leasing communal land to individual ranchers

\begin{tabular}{ll}
\hline 1973-1977 & $\begin{array}{l}\text { Additional privatization of ranches to private } \\
\text { people }\end{array}$ \\
- & $\begin{array}{l}\text { Land allocation to absentee property owners } \\
\text { within ranches in communal land }\end{array}$
\end{tabular}

$1971-1986$
- $\quad$ Political turbulence, war, and internal conflicts (a series of government changes)

\section{Result}

- Sedentarisation of pastoral Bahima elite who acquired ranches

- $\quad$ Traditional pastoralists that did not acquire ranches displaced into other parts of Uganda

- Land conflicts over grazing areas intensified

- encroachment of cattle traditional pastoralists into the reserve

- $\quad$ Corruptly allowing pastoralism into the Lake Mburo Game Reserve

- Land evictions and land grabbing

- Increased reclamation of the wetlands and reduced woodlots

- Land use conflict escalated in the reserve

- Conservation activities in and around Lake Mburo Game Reserve were paralyzed

- Forceful displacement and eviction of people and their livestock into Lake Mburo Game Reserve

- Depopulation of wildlife through extensive poaching and encroachment

- Land in communities abandoned

- Death and reduction of livestock

- Habitat reduction reducing biodiversity

- Adoption of crop farming by traditional cattle keeping and

- An influx of internally displaced people, including migrant agriculturalists

1983 • Status of Lake Mburo Game Reserve uplifted to Lake Mburo National Park (LMNP) (allegedly done as a punishment of local people that did not support the national government at a time)

- $\quad$ Park boundaries delineated
- Animal wildlife conflicts enhanced

- The conservation effort of the park improved

- Escalated human-wildlife conflicts and between herders and elite ranchers

- $\quad$ Overgrazing of marginal land close to the park

\section{Source}

Byakagaba et al., 2018;

Tukahirwa, 2002;

Kafureka, 1992;

Ayorekire, 1999;

Ayorekire et al., 2011;

Ochieng, 2011; Ochieng, 2019;

Tukahirwa, 2002;

Emerton, 1999;

Bernard et al.,2010;

Kamugisha \& Ståhl, 1993

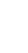

Smith, 2012;

Marquardt, 1994;

Kafureka, 1992;

Emerton, 1999;

Ochieng, 2011; Ochieng, 2019;

Kamugisha \& Ståhl, 1993
Ayorekire, 1999;

Kafureka, 1992;

Hulme \& Infield, 1998;

Emerton, 1999; Namara et al., 1994;

Wurzinger et al., 2009;

Marquardt et al., 1997;

Barrow et al., 1993;

Kamugisha \& Ståhl, 1993

\begin{tabular}{|c|c|c|c|}
\hline 1986 & $\begin{array}{l}\text { Degazettement of part LMNP }- \text { through } \\
\text { reallocation of land to local communities }\end{array}$ & $\begin{array}{l}\text { - } \\
\text { - Ank reduced by } 60 \% \\
\text { An influx of people from other } \\
\text { areas in search of free land } \\
\text { promises } \\
\text { Retaliation of local people against } \\
\text { wildlife authorities } \\
\text { Wildlife and park infrastructure } \\
\text { destroyed }\end{array}$ & $\begin{array}{l}\text { Emerton, } 1999 \\
\text { Hulme \& Infield, 1998; } \\
\text { Namara et al., 1994; } \\
\text { Barrow et al., 1993; } \\
\text { Ntiamoa-Baidu et al., 2001; } \\
\text { Kamugisha \& Ståhl, } 1993\end{array}$ \\
\hline
\end{tabular}




\begin{tabular}{|c|c|c|c|}
\hline 1987-1995 & $\begin{array}{l}\text { - Resettlement of migrants from Luwero under the } \\
\text { Kanyaryeru settlement scheme } \\
\text { - Conservation effort intensified by the park } \\
\text { management (conservation by protectionism } \\
\text { approach) } \\
\text { - Settlement of landless people by Ranch } \\
\text { Restructuring Board (RRB) } \\
\text { - Land tenure restructuring }\end{array}$ & 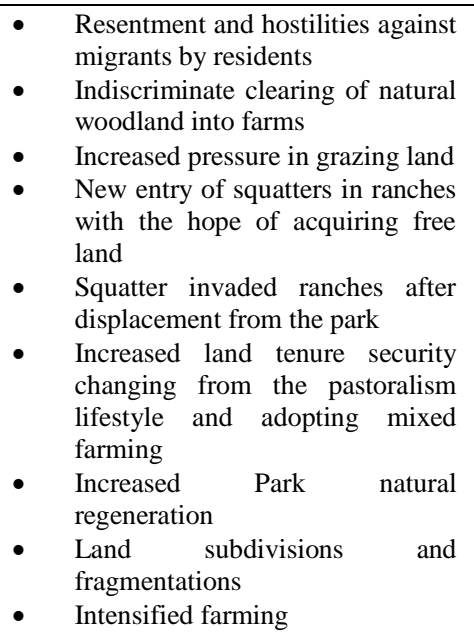 & $\begin{array}{l}\text { Namara, 1996; } \\
\text { Kafureka, 1992; } \\
\text { Hulme \& Infield, 1998; } \\
\text { Byaruhanga \& Kigoolo, } \\
\text { 2005; } \\
\text { UWA, 2015; } \\
\text { Ochieng, 2011; } \\
\text { Ntiamoa-Baidu et al., 2001; }\end{array}$ \\
\hline $\begin{array}{l}1991- \\
1996\end{array}$ & 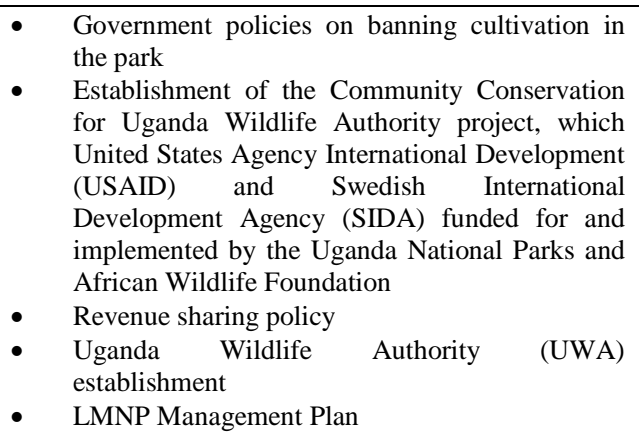 & $\begin{array}{l}\text { - Woodland and grazing land } \\
\text { diminishing outside the park } \\
\text { - Wetland encroachment outside } \\
\text { the park } \\
\text { - Increased conservation in the park } \\
\text { - Modern farming and adoption of } \\
\text { exotic breeds }\end{array}$ & $\begin{array}{l}\text { Emerton, 1999; } \\
\text { Tukahirwa, 2002; } \\
\text { Tukarhirwa, 2004; } \\
\text { Olsen et al. 2004; } \\
\text { Rannestad et al. 2006; } \\
\text { Ochieng et al., 2020 } \\
\text { Ochieng, 2011 }\end{array}$ \\
\hline 2004 & $\begin{array}{l}\text { - Habitat approach focusing on invasive plant } \\
\text { species }\end{array}$ & $\begin{array}{l}\text { - Selective removal of Acacia led } \\
\text { to faster and thicker growth of } \\
\text { other woody species }\end{array}$ & UWA, 2015 \\
\hline $2010-2015$ & $\begin{array}{ll}\text { - } & \text { Agricultural intensification and diversification } \\
\text { - } & \text { Community projects }\end{array}$ & $\begin{array}{l}\text { - Grassland converted to farmlands } \\
\text { - Schools, health centers, and } \\
\text { church construction }\end{array}$ & $\begin{array}{l}\text { FAO, } 2017 \\
\text { Ochieng, } 2019 \\
\text { Ochieng et al., } 2020\end{array}$ \\
\hline $2015-2020$ & $\begin{array}{l}\text { - The general management plan is } \\
\text { ongoing }\end{array}$ & $\begin{array}{l}\text { - } \begin{array}{l}\text { Natural habitat restoration } \\
\text { through natural }\end{array} \\
\text { regeneration within the } \\
\text { park } \\
\text { - Increased pressure on land } \\
\text { attributed to human } \\
\text { population }\end{array}$ & $\begin{array}{l}\text { UWA, } 2015 \\
\text { NEMA, } 2016 \\
\text { USAID, } 2017 \\
\text { USAID, } 2015\end{array}$ \\
\hline
\end{tabular}

Land use and cover change in 1987 and 2020

LULC in 1987 and 2020 are shown in Figures 2 and 3, respectively. The overall accuracies for classified maps of 1987 and 2020 were $80.36 \%$ and $89.81 \%$, respectively. Additionally, the kappa hat classifications for 1987 and 2020 were classified were 0.71 and 0.85 , respectively. The protected area boundaries are also shown.

Figures 4 (a) and (b) show that waterbody, bare land, and built-up had almost the same proportional land coverage in 1987 and 2020. However, the proportion of wetland and grassland cover was higher in 1987 than in 2020. On the other hand, the proportion of woodland and farmland cover in 1987 was lower than in 2020. Furthermore, Table 4 above shows that eroded/bare land did not significantly increase. However, there was a very significant increase in built areas and farmlands. There was an increase in woodland and waterbody cover in the same period. On the other hand, grassland and wetland cover decreased, with wetland decreasing by more than half of its coverage in 1987. 


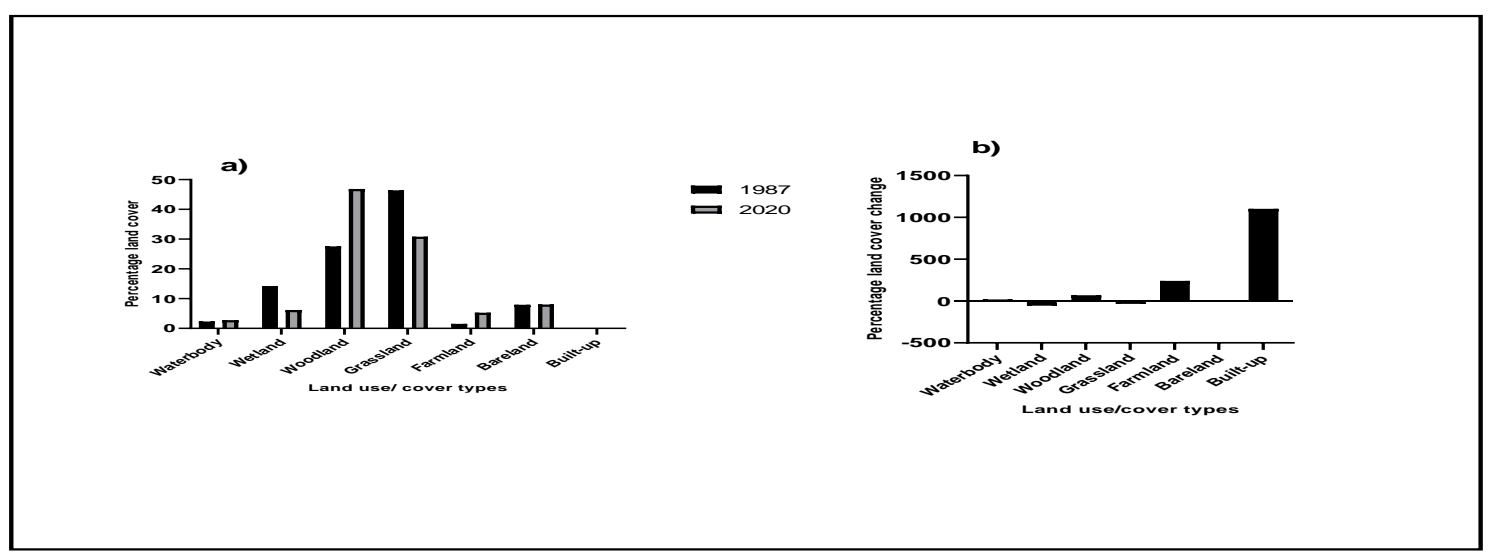

Fig. 4 (a) and (b): The percentage land cover and percentage land cover change between 1987 and 2020 in the Sanga sub-county.

\section{7-2020 LULC change in the protected area of Sanga Subcounty}

The total area of the protected area or the park was about 30,027 hectares. Within the protected area's boundaries (Lake Mburo National Park) of Sanga, the significant change in LULC occurred in wetland, woodland, built-up, and grassland cover, as Figures 5 (a) and (b) show. Wetland cover in 1987 was $19.184 \%$ of the protected area, and in 2020, it was $10.353 \%$, which was a $46.061 \%$ decline at a rate of $1.396 \%$ per year. On the other hand, the percentage occupied by woodland in 1987 was $24.484 \%$, and in 2020 it was $66.353 \%$. Grassland, on the other hand, covered a percentage area of $43.346 \%$ in 1987 and $11.802 \%$ in 2020. Its cover decreased by $72.787 \%$, which was a $2.206 \%$ decline per year. Bare land cover declined by $23.008 \%$, dropping at the area of $0.697 \%$ per year. The built-up area occupied the most negligible percentage in 1987 and 2020 at $0.002 \%$ and $0.005 \%$, respectively. However, built-up had the highest gain with $157.143 \%$ and changed at $4.762 \%$ per year. a)

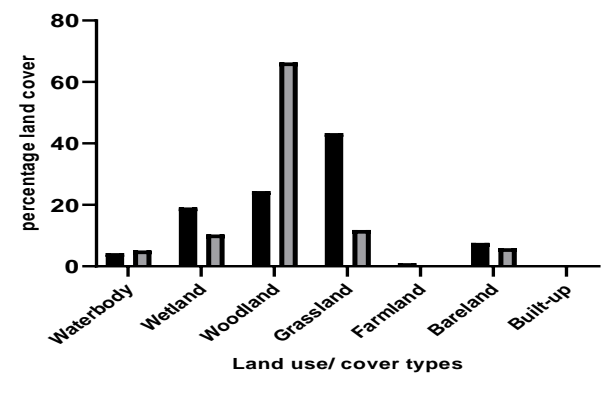

b)

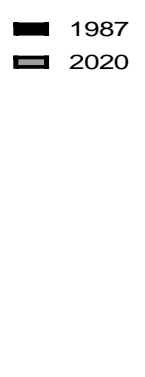

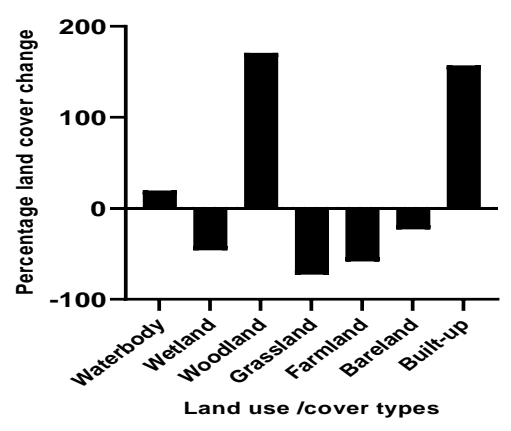

Fig. 5 (a) and (b): The percentage land cover and percentage land cover change between 1987 and 2020 in the protected area.

\section{7-2020 LULC conversion in the protected area of Sanga Subcounty \\ The conversion of LULC between 1987 and 2020 in the protected area occurred mainly in woodland and wetland (Table 4). Wetland lost about 5,756.31 hectares against the gain of 3107.07 hectares. It almost lost to all other land use/cover types except built-up}

area but lost mainly to woodland (2,218.95 hectares), grassland (459.72 hectares), and waterbody (193.68 hectares). Woodland cover, on the other hand, gained 19,912.41 hectares and lost 7,350.03 hectares. The gain was from all land-use types, but it was acquired mainly from wetland (2218.95 hectares), grassland $(10,042.74$ hectares $)$, and bare land (1,203.84 hectares) 
Table 4: Conversion matrix between 1987-2020 in the protected area of Sanga sub-county

\begin{tabular}{|c|c|c|c|c|c|c|c|c|}
\hline \multirow{2}{*}{$\begin{array}{lr}\text { Land } & \text { use/cover } \\
\text { change } & \text { from } \\
1987 & \\
\text { Land } & \\
\text { type } & \end{array}$} & \multicolumn{8}{|c|}{ Land use/cover to in 2020} \\
\hline & Waterbody & Wetland & Woodland & Grassland & Farmland & Bareland & $\begin{array}{l}\text { Built- } \\
\text { up }\end{array}$ & Total \\
\hline Built-up & 0 & 0 & 0.45 & 0 & 0 & 0.18 & 0 & 0.63 \\
\hline Farmland & 1.98 & 0.99 & 188.01 & 40.41 & 2.61 & 73.17 & 0.36 & 307.53 \\
\hline Bareland & 0 & 1.08 & 1203.84 & 403.65 & 15.66 & 668.34 & 0 & 2292.57 \\
\hline Wetland & 193.68 & 2769.39 & 2218.95 & 459.72 & 17.73 & 96.84 & 0 & 5756.31 \\
\hline Waterbody & 1277.19 & 19.08 & 0.27 & 0 & 0 & 0 & 0 & 1296.54 \\
\hline Grassland & 0.36 & 83.88 & 10042.74 & 2083.77 & 68.94 & 725.40 & 1.26 & 13006.35 \\
\hline Woodland & 78.75 & 232.65 & 6258.15 & 554.31 & 23.49 & 202.68 & 0 & 7350.03 \\
\hline Total & 1551.96 & 3107.07 & 19912.41 & 3541.86 & 128.43 & 1766.61 & 1.62 & 30009.96 \\
\hline
\end{tabular}

\section{7-2020 LULC change in unprotected area in} Sanga sub-county

The unprotected area of the Sanga sub-county covered about 25,274 hectares. The changes in LULC occurred mainly in built-up areas, farmlands, woodland, and wetland cover, as shown in Figures 6 (a) and (b). Wetland in 1987 covered $8.05 \%$, but in 2020 its coverage was $0.94 \%$. The percentage decline was $88.34 \%$, at a rate of $2.68 \%$ per year. Woodland occupied $31.30 \%$ of the unprotected area in 1987 and $24.18 \%$ in 2020 . Thus, the percentage area covered by woodland declined by $22.81 \%$, which decreased by $0.69 \%$ per year. Farmland covered $2.17 \%$ and $10.96 \%$ in 1987 and 2020, respectively, increasing by $405.03 \%$ at $12.27 \%$ percent. Built area in 1987 covered $0.01 \%$ and $0.14 \%$ in 2020 respectively but had an enormous gain of $1348.15 \%$ at $40.85 \%$ per year. a)

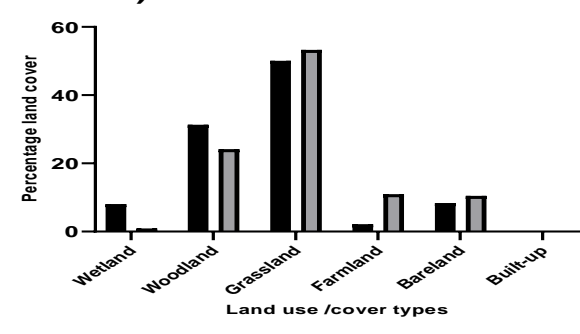

b)

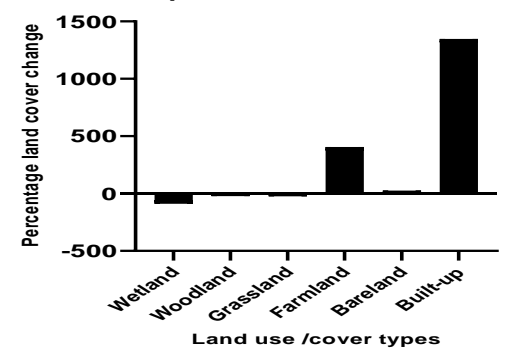

Fig. 6 (a) and (b): The percentage land cover and percentage land cover change between 1987 and 2020 in the unprotected area

\section{7-2020 LULC conversion in the unprotected area} of Sanga Subcounty

Between 1987 and 2020, farmland acquired a total area of 2,766.69 hectares of land and lost 547.74 hectares in the unprotected area of Sanga (Table 5). In that period, 1639.08 hectares of grassland, 181.26 hectares of wetland, 117.90 of bare land, and 802.35 of woodland cover got converted into farmland. Moreover, woodland lost more cover than it gained. It lost $7,905.24$ hectares against a net gain of 6,106.23. More of the woodland cover was converted into $4,854.33$ hectares of grassland, 802.35 hectares of farmland, and 355.05 hectares of bare land. Built gained more land cover of 35.19 hectares and lost only 2.43 hectares.
The gain was mainly from 12.33 hectares of bare land, 21.15 hectares of grassland, and 1.26 hectares of woodland. Bareland cover also increased to 2,647.80 hectares against the net decrease of 2115.54 hectares. The leading cause of increased bare land cover was the loss of 223.92 hectares of farmland, 56.62 hectares of wetland, 1,251.18 of grassland, and 355.05 hectares of woodland. Wetland lost 2,032.83 hectares and gained very little coverage of 237.33 hectares. The significant loss was 666.99 hectares of woodland, 924.03 hectares of grassland, 181.26 hectares of farmland, 56.52 hectares of bare land, and a small portion of 0.27 hectares of built-up. 
Table 5: Conversion matrix between 1987-2020 in the unprotected area of Sanga sub-county

\begin{tabular}{|c|c|c|c|c|c|c|c|}
\hline $\begin{array}{l}\text { Land/cover } \\
\text { change from } 1987\end{array}$ & \multicolumn{7}{|c|}{ Land use/cover change to in $2020(\mathrm{Ha})$} \\
\hline $\begin{array}{l}\text { Land use/cover } \\
\text { types }\end{array}$ & Wetland & Woodland & Grassland & Farmland & Bareland & Built-up & Total \\
\hline Built-up & 0.36 & 0.09 & 1.71 & 0 & 0.27 & 0 & 2.43 \\
\hline Farmland & 0.09 & 105.03 & 192.42 & 26.10 & 223.92 & 0.18 & 547.74 \\
\hline Bare land & 0.54 & 278.01 & 945.90 & 117.90 & 760.86 & 12.33 & 2115.54 \\
\hline Wetland & 203.76 & 666.99 & 924.03 & 181.26 & 56.52 & 0.27 & 2032.83 \\
\hline Grassland & 27.54 & 3168.90 & 6540.57 & 1639.08 & 1251.18 & 21.15 & 12648.42 \\
\hline Woodland & 5.04 & 1887.21 & 4854.33 & 802.35 & 355.05 & 1.26 & 7905.24 \\
\hline Total & 237.33 & 6106.23 & 13458.96 & 2766.69 & 2647.80 & 35.19 & 25252.20 \\
\hline
\end{tabular}

\section{Discussion}

Political and policy decisions and socioeconomic changes in the past were identified as the leading underlying causes of LULC changes (Olson et al., 2004) in Sanga. These drivers influenced LULC to change differently in protected and unprotected areas of the Sanga-Lake Mburo ecosystem due to different land practices in both areas. Government policy changes were prominent causes of the LULC changes. These policies included; park creation, land restructuring, settling of landless people, promoting modern agriculture, and sedentarization of livestock keepers. Sociocultural, economic, demographic factors and political decisions had some influence on ecological changes.

Political and policy decisions may influence the LULC change through the displacement of people, corruption, and reluctance by the government officials to protect natural resources in protected areas from exploitation. Political crisis also paralyzes the conservation activities in the protected area leading to change in LULC. For example, the establishment of ranches, privatization of communal land, and subsequent displacement of landless pastoralists into the then Lake Mburo Game Reserve caused LULC to change in the protected area (Byakagaba et al., 2018; Emerton, 1999; Hulme \& Infield, 1998; Kamugisha and Ståhl, 1993; Tukahirwa, 2002). Migrants established farmlands in the park (Emerton, 1999; Kafureka, 1992; Kamugisha and Ståhl, 1993; Marquardt, 1994; Smith, 2012) without deterrent from the conservationists. Additionally, people who were evicted from communal land and acquired land corruptly in Lake Mburo Game Reserve also caused the loss of vegetation, reclamation of the wetland, and increased grazing pressure (Kamugisha and Ståhl, 1993; Ochieng, 2011; Ochieng, 2019, Tukahirwa, 2002). Therefore, these factors explain why bareland cover was high and woodland cover was low in the protected area in 1987 compared to 2020.

Furthermore, delineating the land exclusively for conservation by the government may reduce land availability to other users leading to competition for natural resources available, causing overexploitation of natural resources. The consequences of the natural resources' exploitation are land conflict and overgrazing, leading to some eroded and bare land as observed outside the park. Creation of the park and degazetting part of it (Ayorekire, 1999; Barrow et al., 1993; Emerton, 1999b; Hulme and Infield, 1998; Kafureka, 1992; Kamugisha and Ståhl, 1993; Marquardt et al., 1997; Namara et al., 1994; Wurzinger et al., 2009) is therefore one the causes of change in LULC (Barrow et al., 1993; Emerton, 1999; Wurzinger et al., 2009). Land conflicts that began in 1983 are still going on (Government of Uganda, 2015), which a local leader with who we interacted confirmed. These disputes lead to poor land management and land fragmentations.

Furthermore, Douglas and Rebecca (2017) agree that the presence of the park is a challenge to the community. The ongoing habitat management implementation in the park have left scarce land for the farmers and pastoralists, thereby causing more pressure on woodland, wetland, and grassland, contributing to eroded/bare land cover and increase of farmlands and settlement (NEMA, 2016; USAID, 2015; USAID 2017). Our field assistant and two other elderlies also agreed that the park had reduced availability of land for grazing and farming, especially near the park where farms and eroded areas are highly experienced due to increased demand for land resources.

The increased conservation effort may restore vegetation cover, as observed by the increase in woodland cover in the park between 1987 and 2020 due to the government's commitment to improving conservation. The establishment of community conservation projects and revenue-sharing policies (Emerton, 1999; Hulme and Infield, 1998; Marquardt et al., 1997; Tukahirwa, 2002) and exclusion of people from the park curbed tree clearing and burning of vegetation (Rannestad et al., 2006). The outcome of these actions and decisions was increased woodland regeneration (Olsen, 2016) and reduced grassland and bare land cover in the park. However, this exclusivity can have an adverse environmental impact in terms of woody encroachment. A haphazard removal of woody 
species can exacerbate the situation. For instance, the attempt by park management to restore habitat to its natural state by reducing woody species backfired as other woody species regenerated very fast (UWA, 2015). The open savanna in 1987 is now covered with woody species (NEMA, 2016; USAID, 2017) of mainly native Acacia species (Williams, 2018), which have reduced habitat in some parts of the park (UWA, 2015).

The immigrations and population increase demand for land for food production and settlement, thereby increasing pressure on woodland. Studies by WoldeYohannes et al. (2018) in Ethiopia report that migrations increase settlements and crop cultivation. In the study area, the refugees who settled near the park from Luwero indiscriminately cleared trees to create land for farming to support themselves after losing their livestock through wars (Mugisha, 2002; Namara, 1996; Olson et al., 2004). In addition to immigration and population increase, land tenure security and land restructuring policy can be attributed to tremendous growth in farmlands and built-up areas (Byaruhanga and Kigoolo, 2005; Hulme and Infield, 1998; UWA, 2015) since the pastoralists adopt settled life. The government's promotion for commercialized and modernized agriculture, further privatization of the land, and sedentarization (Tukahirwa, 2002; Mugisha, 2002; Olson et al., 2004; Byenkya, 2004; Wurzinger et al., 2009) also causes increased settlements and farmlands. Intensified modernized agriculture, for example, rearing of exotic breeds, also requires clearing vegetation to provide grazing land for exotic breeds (Ochieng et al., 2020), causing a reduction in woodland cover outside the park. Katushabe (2014) noted that farmers who adopted exotic species cleared woodland. We also observed that pastoralists are still clearing woodland in their ranches. Built-up areas and farmland increase were further boosted by the government expenditure of proceedings from the sport hunting in supporting arable farming, roads, and semipermanent house construction (Ochieng, 2019; Ochieng et al., 2020). Other factors, such as restricting communal grazing land due to fencing of land by private owners (Kisamba-Mugerwa, 1995) necessitated settlements. Settlements are still growing in Sanga as the population grows, whereby Sanga town and other small villages are developing quickly along the paved and unpaved tracks towards the park's gate (USAID, 2017).

The decrease in woodland cover outside the park was also reported by NEMA (2021), who observed that land cover reduced due to charcoal burning and the need for fuelwood as the population grows (NEMA, 2016; USAID, 2015; USAID, 2017). People in rangeland areas depend on wood for cooking (Mbaziira, 2014) and constructing enclosures for their livestock that keep away predators at night (Olson et al., 2004). Additionally, burning grassland in the Sanga region was a common practice to improve the palatability of the pasture, thereby changing the vegetation climax (Ayorekire, 1999) and reducing vegetation cover. Furthermore, extensive cutting of woodland for charcoal production (Nagasha et al., 2019; NEMA, 2016; USAID, 2015; USAID, 2017) causes the reduction of the woodland vegetation cover (Mugatha, 2002; Mugisha, 2002; Olson et al., 2004).

The culture change (Greg et al., 2019), taboos, and economic development (Mallarach, 2008), for example, changing pastoralists' diet habits from mainly animal-based to a plant-based diet and need to diversity income, can cause change LULC by increasing farmlands. Currently, the pastoralists are practicing mixed farming (Pearson et al., 2015) which is the reason for the increase in farmlands. FAO (2017) reported that some grasslands were further transformed into farmlands as more pastoralists adopted farming.

Soil erosion in hillslopes, along cattle tracks, and around watering points (Marquardt et al., 1997; Namara et al., 1994) and overgrazing may cause the current eroded / bare land cover. Moreover, the movement of livestock and pastoralists during the drought season for the search of pasture destroy soil, grass vegetation, and trees are cut to pave the way for settlement and establishment of livestock enclosures (Greg et al., 2019; Basamba et al., 2016), the practice that sometimes leaves the land bare. For instance, the current bare land cover in the park is caused by the pastoralists who are allowed to access water in the park during the drought season (UWA, 2015; Nagasha et al., 2019). It was also noted by Basamba et al.( 2016), Pearson et al.,( 2015 and Nabasumba et al.( 2016) that commercial ranchers keep a considerable large number of cattle as much as their land can allow leading to grassland and soil destruction (Tukarhirwa, 2004), thereby increasing bare lands

Wetland cover declined in protected and unprotected areas, also a trend observed countrywide (NEMA, 2016). NEMA (2021) also reported a similar finding that between 2005 and 2015, wetlands have declined in the agro-ecological zone where we carried out our study. Wetlands were reduced immensely due to encroachment and ecological changes such as severe droughts (Nagasha et al., 2019; Mugisha et al., 2019; Government of Uganda, 2015; Oxfam, 2008). USAID (2010) observed an increase in temperature by $0.8^{\circ} \mathrm{C}$ during the rainy seasons, which can cause climate variability. Besides prolonged droughts, wetland degradation has been attributed to intensified farming activities, poor farming practices, overgrazing, and increased population growth (NEMA, 2016; Olson et al., 2004; USAID, 2017). The impacts of termites, wetland degradation, overstocking, charcoal burning, and deforestation are attributed to increased global warming leading to frequent droughts (Government of Uganda, 2015) that may have affected the reduction of wetland cover.

\section{Conclusion}

Policy and political decisions mainly influenced LULC change trends observed between 1987 and 2020 in 
protected and unprotected areas. The population increase, sociocultural and socioeconomic changes were also the influence of land use and land cover change outside the park. Accordingly, built-up areas, farmlands, woodlands, grasslands, and wetlands cover changed significantly. The change occurred slightly differently in protected and unprotected areas. In protected areas, bare land and grassland cover decreased. At the same time, woodland increased because of wood encroachment due to government policies and political decisions, which excluded human activities in the park, thereby improving wood regeneration. The decrease in woodland cover and increase in grassland, bare land, built-up, and farmland cover in the unprotected area was attributed to policies changes, population increase, cultural and economic changes. The intensification and modernization of agriculture, presence of the park and population increase, and climate change are causing more pressure on land, thereby causing the disappearance of wetlands, and to some extent, erosion causing bare lands, especially in hillslopes. The existing land dispute may further cause land use and land cover to change, thereby increasing further subdivisions and fragmentation, detrimental to land productivity. Therefore, the future sustainable land use in SangaLake Mburo depends on understanding these patterns of LULCC and strengthening the technical capacity of land management institutions.

\section{Acknowledgment}

We express great gratitude towards The East African Community Scholarship Programme funded by KFW and implemented by IUCEA and Adroit Consult International for financial support.

\section{References}

Alkama, R., Cescatti, A. (2016). Biophysical climate impacts of recent changes in global forest cover. Science, 351(6273), 600-604.

Averbeck, C., Plath, M., Wronski, T., Apio, A. (2012). Effect of human nuisance on the social organisation of large mammals : group sizes and compositions of seven ungulate species in Lake Mburo National Park and the adjacent Ankole Ranching Scheme Original article Effect of human nuisance on the social organ. Wildlife Biology, 18(2), 180-193. https://doi.org/10.2981/11-025

Ayorekire, J. (1999). Conflicting land use in and around Lake Mburo national park, Sanga subcounty, Mbarara District. Economics and Finance, 125.

Ayorekire, J., Ahebwa, W. M., Ochieng, A. (2011). Managing Conservation and Development on Private Land: An Assessment of Managing Conservation and Development on Private Land: An Assessment of Sport hunting Approach around Lake Mburo National Park, Uganda. Makerere University.
Barni, P. E., Fearnside, P. M., de Alencastro Graça, P. M. L. (2015). Simulating deforestation and carbon loss in Amazonia: impacts in Brazil's Roraima state from reconstructing Highway BR-319 (ManausPorto Velho). Environmental Management, 55(2), 259-278.

Barrow, E., Bergin, P., Infield, M., Lembuya, P. (1993). The People's Voice: Partnership and Community Conservation. African Wildlife Foundation, Nairobi.

Basamba, T. A., Tukezibwa, D., Tumushabe, A., Ssekabira, K. (2016). Impacts of Pastoral Activities on Nature Conservation in Western Uganda. International Journal of Ecological Science and Environmental Engineering, 3(2), 42-51.

Behnke, R. H., Scoones, I. (1992). Rethinking range ecology: implications for rangeland management in Africa. International Institute for Environment and Development London.

Bernard, B., Anthony, E., Patrick, O. (2010). Dynamics of Land Use/Cover Trends in Kanungu District SW

Uganda, Journal of Applied Sc. and Env. Man. 14: 67-70

Byakagaba, P., Egeru, A., Barasa, B., Briske, D. D. (2018). Uganda's s rangeland policy: intentions, consequences, and opportunities. Pastoralism: Research, Policy, and Practice, 8(7), 1-16.

Byaruhanga, A., Kigoolo, S. (2005). Information Sheet on Ramsar Wetlands (RIS). Lutembe Bay Wetland System Ramsar Information Sheet on Ramsar Wetlands.

Byenkya, G. S. (2004). IMPACT OF UNDESIRABLE PLANT COMMUNITIES ON THE CARRYING. Texas A\&M University, 1-137.

Congedo, L. (2021). Semi-Automatic Classification Plugin: A Python tool for the download and processing of remote sensing images in QGIS. The Journal of Open Source Software, 6(64), 1-6. https://doi.org/10.21105/joss.03172

Douglas, N., Rebecca, K. (2017). A farmer based evaluation of the group approach to sustainable agricultural development in Sanga Sub-County, Kiruhura district, South-Western Uganda. African Journal of Agriculture and Environment, 3(1), 59 64.

Elias, E., Seifu, W., Tesfaye, B., Girmay, W. (2019). Impact of land use/cover changes on lake ecosystem of Ethiopia central rift valley. Cogent Food \& Agriculture, 5(1), 1-20. https://doi.org/DOI: 10.1080/23311932.2019.1595876

Emerton, L. (1999). Balancing the opportunity costs of wildlife conservation for communities around Lake Mburo National Park, Uganda. IIED.

FAO. (2017). Sustainable Land Management ( SLM) in practice in the Kagera Basin Lessons learned for scaling up at landscape level.

Godar, J., Gardner, T. A., Tizado, E. J., Pacheco, P. (2014). Actor-specific contributions to the deforestation slowdown in the Brazilian Amazon. Proceedings of the National Academy of Sciences, 111(43), 15591-15596. 
Government of Uganda. (2015). District Multi-hazard, Risk and Vulnerability Profile for Kiruhura District.

Greg, F. G., Ndume, H. U., Okoyoyo, F. V. (2019). Way of life and grouping practices of Bahima pastoralists. Advances in Animal Science, Theriogeneology, Genetics and Breeding, 7(3), 2834.

Hulme, D., Infield, M. (1998). Community conservation in practice: a case study of Lake Mburo National Park, Uganda. Institute for Development Policy and Management, University of Manchester.

İşcan, F., Yağc1, C. (2017). Investigation of Changing in Agricultural Land Use after Land Consolidation Projects: A Case Study of Konya/Turkey, International Journal of Environment and Geoinformatics, 4(1), 25-35, doi. 10.30897 /ijegeo.306489

Kafureka, L. B. . (1992). The Dynamics of the Land Question and its Impact on Agricultural Productivity in Mbarara District Lawyer B . M . Kafureka Working Paper No . 25 / 1992 ISBN: 9970-877-46-0 (Issue 25).

Kamugisha, J. R., Ståhl, M. (1993). Parks \& people, pastoralists, and wildlife. Regional Soil Conservation Unit, Swedish International Development Authority.

Katushabe, E. (2014). Reviving the Ankole Longhorns. In Farming Matters (Issue March, pp. 36-39).

Kimiti, K. S., Wasonga, O. V., Western, D., Mbau, J. S. (2016). Community perceptions on Spatiotemporal land use changes in the Amboseli ecosystem, southern Kenya. Pastoralism: Research, Policy, and Practice, 6(24), 1-10. https://doi.org/10.1186/s13570-016-0070-0

Kisamba-Mugerwa, W. (1995). The impact of individualisation on common grazing land resources in Uganda.

Kweka, E. J., Kimaro, E. E., Munga, S. (2016). Effect of deforestation and land use changes on mosquito productivity and development in Western Kenya Highlands: implication for malaria risk. Frontiers in Public Health, 4, 238.

Lapola, D. M., Martinelli, L. A., Peres, C. A., Ometto, J. P. H. B., Ferreira, M. E., Nobre, C. A., Aguiar, A. P. D., Bustamante, M. M. C., Cardoso, M. F., Costa, M. H. (2014). Pervasive transition of the Brazilian land-use system. Nature Climate Change, 4(1), 27-35.

Lawrence, D., Vandecar, K. (2015). Effects of tropical deforestation on climate and agriculture. Nature Climate Change, 5(1), 27-36.

Luwa, J. K., Bamutaze, Y., Majaliwa, J., Waiswa, D., Pilesjö, P., Mukengere, E. B. (2020). Impacts of land use and land cover change in response to different driving forces in Uganda : evidence from a review. African Geographical Review, 00(00), 117. https://doi.org/10.1080/19376812.2020.1832547

Majaliwa, J. G. M., Twongyirwe, R., Nyenje, R., Oluka, M., Ongom, B., Sirike, J., Mfitumukiza, D.,
Azanga, E., Natumanya, R., Mwerera, R., Barasa, B. (2010). The Effect of Land Cover Change on Soil Properties around Kibale National Park in South Western Uganda. Applied and Environmental Soil Science, 1-10. https://doi.org/10.1155/2010/185689

Mallarach, J.-M. (2008). Protected Landscapes and Cultural and Spiritual Values. In Values of Protected Landscapes and Seascapes, IUCN, GTZ, and Obra Social de Caixa Catalunya. Kasparek Verlag, Heidelberg. (Vol. 2, Issues 132-146). https://doi.org/10.2136/sssaj2018.03.0105

Marquardt, M. A. (1994). Settlement and resettlement: Experience from Uganda's national parks and reserves. In World Bank Technical Paper. INOR PUBLICATIES.

Marquardt, M. A., Infield, M., Namara, A. (1997). The socioeconomy, natural resource use, and attitudes towards the park of communities living in and around Lake Mburo National Park: report of a rapid rural appraisal.

Mbaziira, J. (2014). The Effects of Land Use Cover Change on Rangeland Ecosystems in Kakooge Subcounty Nakasongola District, Uganda. Makerere University.

Mbaziira, J. (2019). Land cover and land use change analysis : Its impacts on rangeland ecosystems in Kakooge County, Nakasongola district. Journal of Science \& Sustainable Development, 6(2), 167180.

Mugisha, S. (2002b). Root Causes Of Land Cover / Use Change In Uganda: An Account Of The Past 100 Years (No. 2; Uganda-LUCID).

Murty, D., Kirschbaum, M. U. F., Mcmurtrie, R. E., Mcgilvray, H. (2002). Does conversion of forest to agricultural land change soil carbon and nitrogen? A review of the literature. Global Change Biology, $8(2), 105-123$.

Mwanjolo, M. G. J., Bernard, B., Paul, M. I., Joshua, W., Sophie, K., Cotilda, N., Bob, N., John, D., Edward, S., Barbara, N. (2018). and Future Land Use Systems in Uganda. Land, 7(132), 1-17. https://doi.org/10.3390/land7040132

Nabasumba, D., Bahati, G. E. J., Katwesigye, G. (2016). Utilisation and conservation status of indigenous woody plant species in a sedentary pastoral production system in southwestern. Uganda Journal of Agricultural Sciences, 17(2), 125-137. https://doi.org/https://dx.doi.org/10.4314/ujas.v17i2 .1

Nagasha, J. I., Ocaido, M., Kaase-bwanga, E. (2019). Attitudes, Practices, and Knowledge of Communities Towards Climate Change Around Lake Mburo National Park Uganda: A Gender Centered Analysis Attitudes, Practices and Knowledge of Communities Towards Climate Change Around Lake Mburo National Park Uganda. African Social Science Review, 10(1).

Nakalembe, C., Dempewolf, J., Justice, C. (2017). Agricultural land use change in Karamoja Region, Uganda. Land Use Policy, 62, 2-12. 
Namara, A. (1996). Socioeconomic Survey of Fishing Villages in the Buffer Zone of Lake Mburo National Park Socioeconomic Survey of Fishing Villages in the Buffer Zone of Lake Mburo National Park. Makerere Institute of Social Research and the Land Tenure Center, 15, 1-23.

Namara, A., Marquardt, M. A., Infield, M. (1994). Socioeconomic survey of communities in the buffer zone of Lake Mburo National Park.

NEMA. (2007). State of the Environment Report for Uganda 2006/2007.

NEMA. (2016). National State Of The Environment Report For Uganda 2014.

NEMA. (2021). Land and Soil Improvement Accounts for Uganda.

Ntiamoa-Baidu, Y., Zeba, S., Mboje Gamassa, D. G., Bonnehin, L. (2001). Principles in practice: staff observation of conservation projects in Africa. Biodiversity Support Program, Washington, DC (EUA).

Nyamasyo, S. K., Kihima, B. O. (2014). Changing Land Use Patterns and Their Impacts on Wild Ungulates in Kimana Wetland Ecosystem, Kenya. International Journal of Biodiversity, 2014, 1-10.

Ochieng, A. (2011). Linking Tourism, Conservation and Livelihoods: An analysis of Sport Hunting around Lake Mburo National Park, Uganda. Wageningen University and Research Centre (WUR).

Ochieng, A. (2019). Killing nature to save it? An analysis of two sport hunting policy arrangements in Uganda [Wageningen Graduate School of Social Sciences]. https://doi.org/https://doi.org/10.18174/466995 iv

Ochieng, A., Visseren-Hamakers, I. J., Van Der Duim, R. (2020). Sport Hunting to Save Nature? The Case of Uganda. Conservation \& Society, 18(4), 340354. https://doi.org/https://doi.org/10.4103/cs.cs

Olofsson, P., Foody, G. M., Herold, M., Stehman, S. V, Woodcock, C. E., Wulder, M. A. (2014). Remote Sensing of Environment Good practices for estimating area and assessing accuracy of land change. Remote Sensing of Environment, 148, 4257. https://doi.org/10.1016/j.rse.2014.02.015

Olsen, M. (2016). Effect of vegetation encroachment on Macrotermes subhyalinus ( Rambur) activity and associated mound vegetation, in Lake Mburo National Park, Uganda. Norwegian University of Life Sciences.

Olson, J., Berry, L. (2003). Land degradation in Uganda: its extent and impact. Available at Lada. Virtual centre. Org/Eims/Download. Asp, 3-14.

Olson, J. M., Misana, S., Campbell, D. J., Mbonile, M., Mugisha, S. (2004). The Spatial Patterns and Root Causes of Land Use Change in East Africa (No. 47; Land Use Change Impacts and Dynamics (LUCID) Project Working Paper).

Pearson, A. L., Mayer, J. D., Bradley, D. J. (2015). Coping with Household Water Scarcity in the Savannah Today: Implications for Health and Climate Change into the Future. Earth Interactions,
19(8), 1-14. https://doi.org/10.1175/EI-D-140039.1

Rannestad, O. T., Danielsen, T., Moe, S. R., Stokket, S. (2006). Adjacent Pastoral Areas Support Higher Densities of Wild Ungulates during the Wet Season than the Lake Mburo National Park in Uganda. Journal of Tropical Ecology, 22(6), 675-683. https://doi.org/10.1017/S0266467406003610

Richter, D. D., Markewitz, D., Heine, P. R., Jin, V., Raikes, J., Tian, K., Wells, C. G. (2000). Legacies of agriculture and forest regrowth in the nitrogen of old-field soils. Forest Ecology and Management, 138(1-3),

233-248. https://doi.org/https://doi.org/10.5897/AJAR2020.1 4959

Robert, T., Sarah, N. A., Samuel, O. (2020). Drivers and restrictions of range pasture improvement by agro-pastoralists in Kiruhura District, Uganda. African Journal of Agricultural Research, 16(11), 1514-1530.

https://doi.org/10.5897/AJAR2020.14959

Sambou, S., Lykke, A. M., Sambou, H., Guiro, I., Sambou, B., Mbow, C. (2015). Land use-land cover change and drivers of deforestation in the Patako protected area (Center-West of Senegal). American Journal of Environmental Protection, 4(6), 306.

Samndong, R. A., Bush, G., Vatn, A., Chapman, M. (2018). Institutional analysis of causes of deforestation in REDD+ pilot sites in the Equateur province: Implication for REDD+ in the Democratic Republic of Congo. Land Use Policy, 76, 664-674.

Sintayehu, D. W., Kassaw, M. (2019). Impact of land cover changes on elephant conservation in babile elephant sanctuary, Ethiopia. Biodiversity International Journal, 3(2), 65-71. https://doi.org/10.15406/bij.2019.03.00129

Smith, H. (2012). The Overlap between Conservation and Development Organisations in the Albertine Rift, Western Uganda (No. 7; PCLG Discussion Paper, Issue 07).

Smith, P., Clark, H., Dong, H., Elsiddig, E. A., Haberl, H., Harper, R., House, J., Jafari, M., Masera, O., Mbow, C. (2014). Agriculture, forestry and other land use (AFOLU) (In Climate Change 2014: Mitigation of Climate Change. IPCC Working Group III Contribution to AR5). Cambridge University Press.

Solberg, S., May, J., Bogren, W., Breidenbach, J., Torp, T., Gizachew, B. (2018). Interferometric SAR DEMs for forest change in Uganda 2000 2012. Remote Sensing, 10(2), 228.

Tibezinda, M., Wredle, E., Sabiiti, E. N., Mpairwe, D. (2016). Feed resource utilization and dairy cattle productivity in the agro-pastoral system of South Western Uganda. African Journal of Agricultural Research, 11(32), 2957-2967. https://doi.org/10.5897/AJAR2016.10785

Tukahirwa, J. M. B. (2002). Policies, people and landuse change in Uganda: A case study in Ntungamo, Lake Mburo and Sango Bay sites (No. 17; LUCID 
Working Paper). International Livestock Research Institute.

Tukarhirwa, J. (2004). Land use change-associated deterioration in soil quality in Uganda: a case study from Sango Bay, Lake Mburo national park area, and Kabale/Ntungamo Districts Border area (No. 41; LUCID Working Paper). International Livestock Research Institute

USAID. (2010). A Climate Trend Analysis of Uganda.

USAID. (2015). Uganda Environmental Threats And Opportunities Assessment ( Etoa) Final Etoa Report Uganda Environmental Threats And Opportunities Assessment (Etoa) Final Etoa Report.

USAID. (2017). Climate Risks To Conservation In Uganda: An Assessment of Selected Regions (Issue May).

UWA. (2015). Lake Mburo Conservation Area General Management Plan (2015 - 2025).

Williams, L. (2018). The Rothschild's giraffe as a potential biological controller of invasive native Acacia species in Lake Mburo National Park, Uganda. Norwegian University of Life Sciences.

WoldeYohannes, A., Cotter, M., Kelboro, G., Dessalegn, W. (2018). Land use and land cover changes and their effects on the landscape of Abaya-Chamo Basin, Southern Ethiopia. Land, 7(1), 2. https://doi.org/doi:10.3390/land7010002

Wurzinger, M., Okeyo, A. M., Semambo, D., Souml, J. (2009). The sedentarisation process of the Bahima in Uganda: An emic view. African Journal of Agricultural Research, 4(11), 1154-1158. 